\title{
Irradiance Optimation for Growing Spirulina fusiformis: Biomass, Phycocyanin and Protein Production
}

\author{
Awalina Satya ${ }^{a, *}$, Tjandra Chrismadha ${ }^{a,}$, Ika Atman Satya ${ }^{\text {b }}$ \\ ${ }^{a}$ Research Center for Limnology, Indonesian Institute of Sciences; Cibinong Science Center, Jln. Raya Bogor \\ Jakarta km 46 Cibinong Bogor, 16911, INDONESIA \\ *Email: awalina@limnologi.lipi.go.id
}

${ }^{\mathrm{b}}$ Research Center for Informatics, Indonesian Institute of Sciences; Cibinong Science Center, Jln. Raya Bogor Jakarta km 46 Cibinong Bogor, 16911, INDONESIA

\begin{abstract}
The optimization of cyanobacterium microalgae cultivation technology to provide the need for food or feedstocks has recently attracted many investigators. An optimum operation on microalgae cultivation is important to reduce the excessive workload on the aquatic environment. Therefore, this study describes how the varied irradiance (2000 lux, 4000 lux, 6000 lux, 8000 lux, and 10,000 lux) treatments on a bubble column photobioreactor system affected biomass production, phycocyanin, and protein from cyanobacterium Spirulina fusiformis. The objective of this study was to obtain the optimum irradiance for producing maximum biomass, phycocyanin, and protein simultaneously. The results demonstrated some findings those were: 1) irradiance 10,000 lux made doubling time of growth earliest (only 24 hours) while 2,000 lux doubled within five days later; 2) light response curve showed that the increase of biomass concentration was linear with the increasing of irradiance; 3) a predictive model (Response Surface Method) proof that the most optimum quantity of the biomass $\left(0.58 \pm 0.035 \mathrm{gL}^{-1}\right.$ dry weight), chlorophylla $(0.090 \pm 0.023 \%$ dry weight $)$, and phycocyanin $(2.44 \pm 0.00 \mathrm{~g} / \mathrm{L}$ dry weight $)$ were obtained on 10,000 lux, while protein contents of $79.18 \pm 5.47 \%$ dry weight attained on the irradiance of 6000 lux. The maximum productivity of the biomass, chlorophyll-a, phycocyanin, and protein was $\sim \mathrm{P}_{\text {biomass }}$ of 24.95 $\mathrm{mg} / \mathrm{L}$.day; $\mathrm{P}_{\text {chl-a }}$ of $2.25 \mathrm{E}-02 \mathrm{mgL}^{-1}$.day ${ }^{-1} ; \mathrm{P}_{\text {phycocyanin }}$ of $1.88 \mathrm{E}-02 \mathrm{mg} / \mathrm{L}$.day; and $\mathrm{P}_{\text {protein }}$ of $17.56 \mathrm{mgL}^{-1}$.day ${ }^{1}$. Enhancement of irradiance up to 5 folds lead to the increasing of biomass chlorophyll-a, phycocyanin, and protein productivity, attained to $1.7,5.01,4.13$, and 2.81 folds, respectively. The irradiance had a significant influence on the production of the metabolites; therefore, the irradiance must be optimized.
\end{abstract}

Keywords: cyanobacterium microalgae, irradiance, photobioreactor, phycocyanin, Spirulina fusiformis,

\section{INTRODUCTION}

Cyanobacterium microalgae are widely distributed both in freshwater and marine environments. These microorganisms are ancient photosynthetic prokaryotes and play a role as primary biomass producers at the base of the aquatic food chain. Some cyanobacteria are capable of fixing the atmospheric nitrogen, therefore, favored being a symbiont with other microorganism which advantageous for preserving the fertile environment. These microalgae excellently produce various secondary metabolites which contain biologically active ingredients. Numerous downstream products can be made from these active ingredients, such as antifungal, antibacterial, antitumor, immunosuppressant, and immunostimulant. The most cultivated worldwide cyanobacterium is filamentous Spirulina (Arthrospira). This cyanobacterium has already known as raw material for making edible and toxic-free dried 
biomass. They are commonly being used as a protein supplement in poultry and livestock feeds. Therefore, the cultivation of Spirulina (Arthrospira) is attractive (Bland and Angenent, 2016; Koller et al., 2014; Vanthoor-Koopmans et al., 2013).

Ordinarily, farmers cultivate the Spirulina (Arthrospira) in open ponds for economic reasons (low-cost for construction, operation, and maintenance) and the easiness to operate. However, numerous drawbacks are adhered, such as the low biomass productivity (less than $15 \mathrm{gm}^{-}$ ${ }^{2}$.day ${ }^{-1}$ ), the difficulty to maintain the optimum cultivation parameters, high rate of evaporation, and susceptibility towards contamination. Accordingly, to produce high-value microalgae products, open ponds are mostly considered to be unreliable. It is essential to implement a closed system such as a photobioreactor system that controls the operating conditions, culture reproducibility, and avoiding contamination. The optimum use of photobioreactor system also can reduce the excessive workload of the aquatic environment (Craggs et al., 2014; Johnson et al., 2018; Whitton et al., 2015).

Under a favorable growth medium, the environmental factors, one of them is irradiance, become the most critical key for biomass productivity, not only to assure its quantity but also for quality. Irradiance is defined as the total amount of radiation reaching a point from all directions in space on every wavelength. Nevertheless, microalgae only can use a range of 400-700 nm for conducting photosynthesis (known as Photosynthetically Active Radiation, P.A.R.) (Guler et al., 2019; Dejsungkranont et al., 2017; Johnson et al., 2018). Therefore, this study aimed to obtain the optimum irradiance applied in a photobioreactor system to enhance the maximum Spirulina fusiformis biomass production and the chlorophyll phycocyanin and protein contents.

\section{METHODS}

This method section describes the experimental design and analytical methods.

\section{Microalgae and Culture Media}

A local microalgae strain of Spirulina fusiformis was provided by the Lab. of Planktonolgy-RC for Limnology, Indonesian Institute of Sciences, Cibinong. It was grown in Zarrouk medium, which composition is described in Table 1. The microalgae were proliferated under irradiance of 2000 lux for three days and continuously aerated (flow rate of $3 \mathrm{Lmin}^{-1}$ ) before inoculated into 15 sets of bubble column photobioreactors (each has working volume, $\mathrm{V}_{\text {working }}$ of $2.0 \mathrm{~L}$ ). All reagents were analytical grade from Merck-Germany.

Table 1. Ingredients of Zarrouk's medium (Andersen, 2005)

\begin{tabular}{|c|c|c|}
\hline$\bullet$ & \multicolumn{2}{|c|}{ Macro elements (in one L of Demineralized water) } \\
\hline & - $\mathrm{NaHCO}_{3}$ & $10 \mathrm{~g}$ \\
\hline & - $\mathrm{KNO}_{3}$ & $1 \mathrm{~g}$ \\
\hline & - $\mathrm{NaCl}$ & $1 \mathrm{~g}$ \\
\hline & - $\mathrm{Kcl}$ & $1 \mathrm{~g}$ \\
\hline & - $\mathrm{FeCl}_{3}$ & $0.01 \mathrm{~g}$ \\
\hline & - $\mathrm{Na}_{2}$ EDTA & $0.08 \mathrm{~g}$ \\
\hline & - $\mathrm{H}_{3} \mathrm{PO}_{4}$ & $0.25 \mathrm{ml}$ \\
\hline & - Trace element A & $1 \mathrm{ml}$ \\
\hline & - Trace element B & $1 \mathrm{ml}$ \\
\hline \multirow[t]{13}{*}{ - } & \multicolumn{2}{|c|}{ Macro elements (in one $L$ of Demineralized water) } \\
\hline & \multicolumn{2}{|l|}{ a. Trace element A } \\
\hline & - $\mathrm{H}_{3} \mathrm{BO}_{3}$ & $2.86 \mathrm{~g}$ \\
\hline & - $\mathrm{MnCl}_{2}, 4 \mathrm{H}_{2} \mathrm{O}$ & $1.81 \mathrm{~g}$ \\
\hline & - $\mathrm{ZnSO}_{4}, 7 \mathrm{H}_{2} \mathrm{O}$ & $0.22 \mathrm{~g}$ \\
\hline & - $\mathrm{Na}_{2} \mathrm{MoO}_{4}, 2 \mathrm{H}_{2} \mathrm{O}$ & $0.015 \mathrm{~g}$ \\
\hline & - $\mathrm{CuSO}_{4}, 5 \mathrm{H}_{2} \mathrm{O}$ & $0.079 \mathrm{~g}$ \\
\hline & \multicolumn{2}{|l|}{ b. Trace element B } \\
\hline & - $\mathrm{COCl}_{2}, 6 \mathrm{H}_{2} \mathrm{O}$ & $0.04398 \mathrm{~g}$ \\
\hline & - $\mathrm{NH}_{4} \mathrm{VO}_{3}$ & $0.02296 \mathrm{~g}$ \\
\hline & - $\mathrm{CaCl}_{2}$ & $0.09600 \mathrm{~g}$ \\
\hline & - $\mathrm{NiSO}_{4}, 7 \mathrm{H}_{2} \mathrm{O}$ & $0.04785 \mathrm{~g}$ \\
\hline & - $\mathrm{Na}_{2} \mathrm{WO}_{4}, 2 \mathrm{H}_{2} \mathrm{O}$ & $0.01794 \mathrm{~g}$ \\
\hline
\end{tabular}


Figure 1 presents the process design of this study. A system of the bubble column photobioreactor (P.B.R.) configured from a glass bottle (inner diameter of $20 \mathrm{~cm}$ and height of 30 $\mathrm{cm}$ ) contained $\mathrm{V}_{\text {working of }} 2.0 \mathrm{~L}$ (Schott-Germany) filled with Zarrouk medium. These bottles are equipped with a rubber plug with two holes (one for the aeration tubing port and another for the air ventilating port). Continuous aeration was obtained from a blower pump provided air streamflow of $3 \mathrm{Lmin}^{-1}$ into P.B.R.s under irradiance of a 500 Watts Halogen Lamp. After stabilization for 30 minutes, $100 \mathrm{~mL}$ of inoculum was added into P.B.R.s. Irradiance treatment varied by adjusting the distance between the P.B.R. and the light source through lux measurement using a digital lux meter (Lutron$\mathrm{X} 310$, China). The photoperiod was $24 \mathrm{~h} / 0 \mathrm{~h}$ light/dark cycle.

\section{Obtaining the observed parameters and Analytical methods}

Daily measurements were proceeded to determine optical density at $480 \mathrm{~nm}$ using a UVVis spectrophotometer UV1800 (ShimadzuJapan). Meanwhile, a portable YSI-digital instrument was used for the measurement of $\mathrm{pH}$, water temperature $\left(T_{w}\right)$, and air temperature $\left(T_{a}\right)$.

A sampling of the culture broth was conducted every week within 31 days to measure biomass, phycocyanin, chlorophyll-a, and protein. For dry weight biomass determination, a $10 \mathrm{~mL}$ sample was filtered through the pre-weighed paper GF/C (Whatman, U.S.A.) and washed twice with demineralized water. Retained biomass was ovendried at $100^{\circ} \mathrm{C}$ for 1 hour until consistent weight is reached.

Chlorophyll-a content was determined by the three chromatic methods (at the wavelength of 664,647 , and $630 \mathrm{~nm}$ ) using spectrophotometer UV1800 (Shimadzu-Japan). The obtained absorbances were then corrected for turbidity by subtracting those values at $750 \mathrm{~nm}$ (APHAAWWA, 1992).

Total protein in microalgae biomass was measured spectrophotometrically according to the Lowry method. A calibration curve of Bovine Serum Albumin was prepared to determine protein content (Lowry et al., 1951).

Phycocyanin extraction with phosphate buffer solution $(\mathrm{pH} \sim 7)$ and content measurement spectrophotometrically at wavelength $620 \mathrm{~nm}$ using spectrophotometer UV1800 (ShimadzuJapan) was conducted according to Boussiba and Richmond (1979). All data of chlorophyll-a, phycocyanin and protein contents are expressed in $\%$ of dry weight.

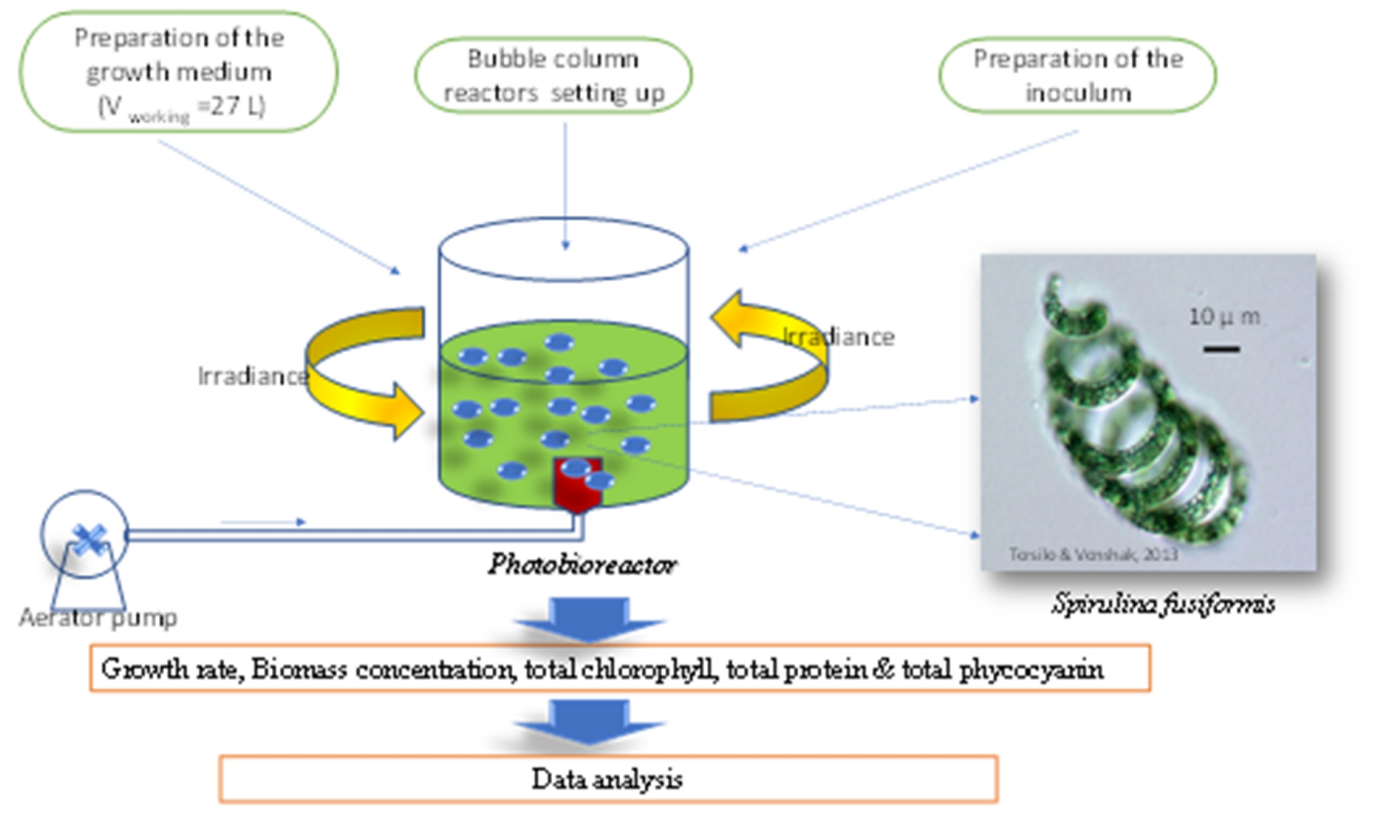

Figure 1. The process design of every single bubble column photobioreactor (P.B.R.). Total operated P.B.R. was 15 sets in every running. 


\section{Statistical analysis}

The presented data are the average of three independent experiments with three replications. The standard deviations of each set of experiments are represented in the corresponding figures (expressed as error bars).

Optimization of irradiance treatment was conducted using Response Surface Methodology. The influence of irradiance and biomass concentration (independent variables) on the metabolites (e.g. protein) production (dependent variable) was assessed through non-linear regression. This assessment was also conducted on the production of phycocyanin and chlorophyll-a. The quality of the fitted equations model was expressed by the coefficient of determination $\left(\mathrm{R}^{2}\right)$, and its statistical significance was checked by the Durbin-Watson statistic, the Kolmogorov-Smirnov test, normality test, and covariance test. Results were analyzed using Sigma Plot for windows version 10-Systat Software Inc.-Germany.

\section{RESULTS AND DISCUSSION}

The operational condition parameter throughout this study is presented in Table 2. It can be noted that both air temperature and water temperature ranges are typical for tropical climates. Spirulina fusiformis grew in the alkaline $\mathrm{pH}$ values, which favors the typical alkaliphilic microalgae. The optical density (O.D.) of inoculant stock broth was 16 magnitudes higher than the initial culture broth. This higher O.D. was designed to ensure the adequate biomass quantity for initiating the subsequent Spirulina fusiformis cultivation in the P.B.R. system. Meanwhile, the irradiance range was well adjusted according to the research design of this study.

Table 2. The operational parameter in this study

\begin{tabular}{llll}
\hline Parameter & Inoculant stock broth & Initial culture broth & Final culture broth \\
\hline Air temperature $\left({ }^{\circ} \mathrm{C}\right)$ & 29 & 28 & 30 \\
Water temperature $\left({ }^{\circ} \mathrm{C}\right)$ & 29.5 & 29.1 & $29.1-30$ \\
$\mathrm{pH}$ & 9.05 & $8.72-8.84$ & $10.48-10.64$ \\
Optical Density at $\lambda$ 480nm & 0.98 & $0.025-0.060$ & $0.591-2.040$ \\
Irradiance (lux) & - & $2,000-10,000$ & $2,000-10,000$ \\
\hline
\end{tabular}
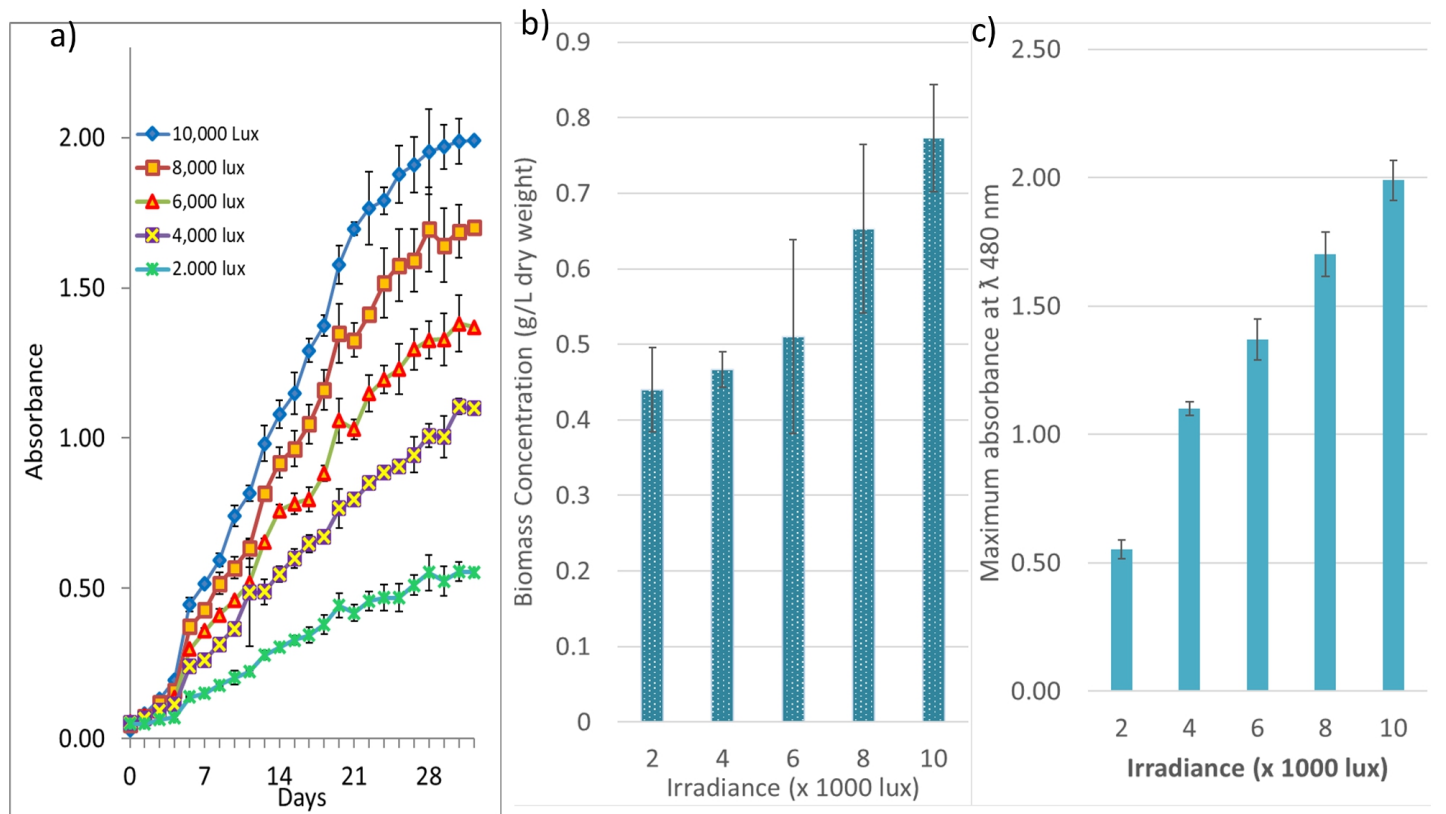

Figure 2. Time profile of absorbance at $\chi 480 \mathrm{~nm}$ of Spirulina fusiformis cultivar (a), biomass concentration (b), maximum absorbance in every irradiance treatment (c). Data are expressed as mean values \pm deviation $(\mathrm{n}=3)$. 
The changes of the O.D. (absorbance at $\chi 480$ $\mathrm{nm}$ ) of Spirulina fusiformis cultivar were depicted in Figure 2a. It was clear that irradiance enhanced algal growth and biomass concentration. Within the early sixth days, the irradiance of $10 \mathrm{k}$ lux leads to 15 magnitudes of O.D. compared to its initial value. Meanwhile, in $8 \mathrm{k}$ lux, $6 \mathrm{k}$ lux, and 4 $\mathrm{k}$ lux were only observed $\sim 5$ magnitudes. The lowest magnitude occurred in P.B.R. with $2 \mathrm{k}$ lux irradiance, which only reached almost three magnitudes. Figures $2 \mathrm{~b}$ and $2 \mathrm{c}$ complemented with Figure 2a; therefore, this result shows that higher irradiance promoted faster growth of the Spirulina fusiformis cultivar. This finding is also in line with other reports emphasizing the importance of light to biomass concentration and carbon dioxide bio-sequestration (Mohsenpour Willoughby, 2016; Morais Costa, 2007; Ores et al., 2016; Zhao et al., 2015).

Comparing three metabolites' products was characterized by the mean and standard deviation between three replicates of measurements in every irradiance treatment (Figure 3a to Figure 3c). The protein content attained the highest content (79.18\% dry weight) when the cultivar was irradiated with $6 \mathrm{k}$ lux. Meanwhile, chlorophyll-a contents (ranged $0.080-0.085 \%$ dry weight) were not significantly differed when irradiated with $4 \mathrm{k}$ lux to $10 \mathrm{k}$ lux. Phycocyanin content averagely higher up to 30 magnitudes than chlorophyll-a content. However, it was found that there is no distinction among irradiance treatments (4 k lux$10 \mathrm{k}$ lux) to the phycocyanin content. The significant difference only appeared on irradiance of $2 \mathrm{k}$ lux, both on chlorophyll-a and phycocyanin contents.

Protein content in this study was confirmed with other reports denoted that microalgae biomass is considered a dietary supplement. Since it contains protein up to $50-70 \%$ of dry weight, the highest protein content $(79.18 \%$ dry weight) was observed in the $6 \mathrm{k}$ lux treatment in this study. Afterwards, the protein content tended to decline.

Table 3 shows the average productivity of biomass, chlorophyll-a, phycocyanin, and protein from Spirulina fusiformis cultivar in this study. The enhancement of irradiance up to 5 folds lead to the increasing of biomass attained to 1.7 folds. Higher magnifications occurred on chlorophyll-a, phycocyanin, and protein that were achieved on 5.01, 4.13, and 2.81 folds. However, biomass productivity of Spirulina fusiformis in this study (range 14.19-24.95 mg/.day) is lower compared to another report, since according to the report of de Morais and Vieira Costa (2007), biomass productivity of Spirulina $s p$ grown in a column photobioreactor range was $40-140 \mathrm{mgL}^{-1}$. day ${ }^{-1}$.

The productivity range of phycocyanin content in Spirulina fusiformis in this study was also lower than Spirulina platensis grown in various photobioreactors whose productivity range was 14-125 mgL mblay $^{-1}$ (Chen et al., 2013; Mary Leema et al., 2010).

Protein productivity of Spirulina fusiformis in this study was lower 13 folds, compared to data as reported by Michael et al. (2019) that in their study, Spirulina fusiformis grown in medium ordinary Zarrouk gave protein productivity of 234 mg/L.day.This difference seems caused by a distinct implemented dark/light cycle $(12 \mathrm{~h} / 12 \mathrm{~h}$ of irradiance 4500 lux).

Rangel-Yagui Cde et al. (2004) reported that cultivation of $S$. platensis at different light intensities and utilizing urea as the nitrogen source showed chlorophyll-a productivity range of $0.45-1.32 \mathrm{mgL}^{-1}$.day-1. In this study, Spirulina fusiformis showing a lower range (50-100 magnitudes).

Table 3. The average productivity of biomass and metabolites of Spirulina fusiformis in a bubble column reactor system.

\begin{tabular}{crrrr}
\hline Irradiance (x1000 lux) & $\mathrm{P}_{\text {biomass }}\left(\mathrm{mgL}^{-1} . \mathrm{day}^{-1}\right)$ & $\mathrm{P}_{\text {Chl-a }}\left(\mathrm{mgL}^{-1} . \mathrm{day}^{-1}\right)$ & $\mathrm{P}_{\text {phycocyanin }}\left(\mathrm{mgL}^{-1}\right.$. day $\left.^{-1}\right)$ & $\mathrm{P}_{\text {Protein }}\left(\mathrm{mgL}^{-1}\right.$. day $\left.^{-1}\right)$ \\
\hline 2 & 14.19 & $4.48 \mathrm{E}-03$ & $4.56 \mathrm{E}-03$ & 6.25 \\
4 & 15.05 & $1.11 \mathrm{E}-02$ & $8.66 \mathrm{E}-03$ & 10.28 \\
6 & 16.45 & $1.31 \mathrm{E}-02$ & $1.02 \mathrm{E}-02$ & 13.03 \\
8 & 21.08 & $1.78 \mathrm{E}-02$ & $1.40 \mathrm{E}-02$ & 15.32 \\
10 & 24.95 & $2.25 \mathrm{E}-02$ & $1.88 \mathrm{E}-02$ & 17.56 \\
\hline
\end{tabular}


Determination of the optimum irradiance for producing chlorophyll-a, phycocyanin, and protein content in the Spirulina fusiformis cultivar biomass conducted through response surface methodology (R.S.M.) (Figure $4 \mathrm{a}$ to $4 \mathrm{c}$ ). This method relates between independent variables (irradiance and dry weight biomass) and dependent variable (metabolite product). This method was recently popular and used in some

a)

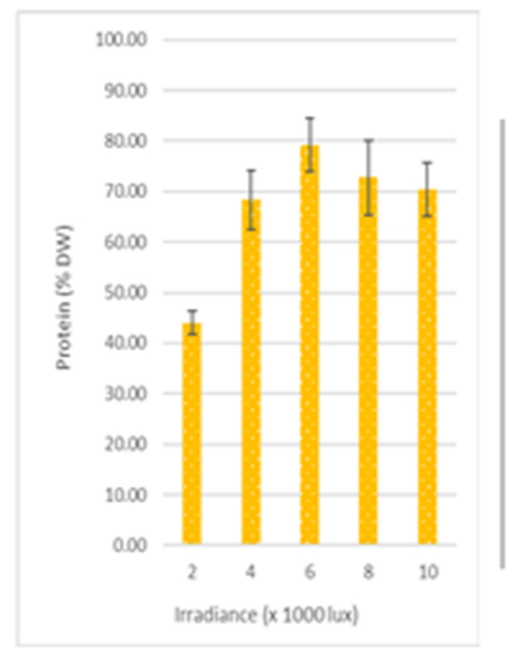

b)

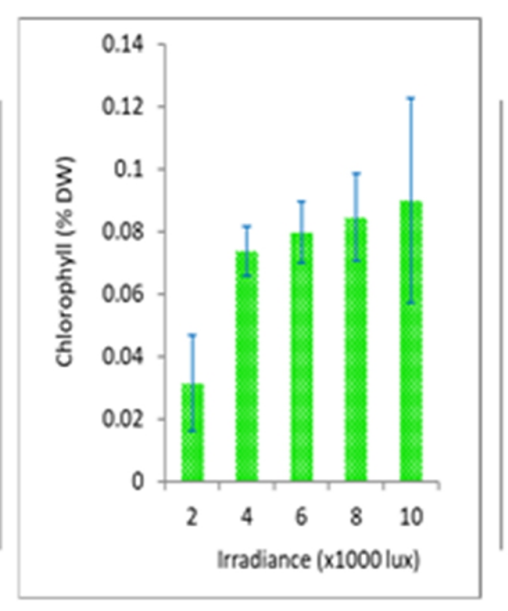

reports that deal with optimization of the operational parameter in microalgae cultivation (Ho et al., 2012; Jacob-Lopes, Cacia Ferreira Lacerda, et al., 2008; Jacob-Lopes, Scoparo, et al., 2008). Since there were three metabolites products, three graphical visualizations (3 dimensions surface plots) were made, as seen in Figures $4 \mathrm{a}$ to $4 \mathrm{c}$.

c)

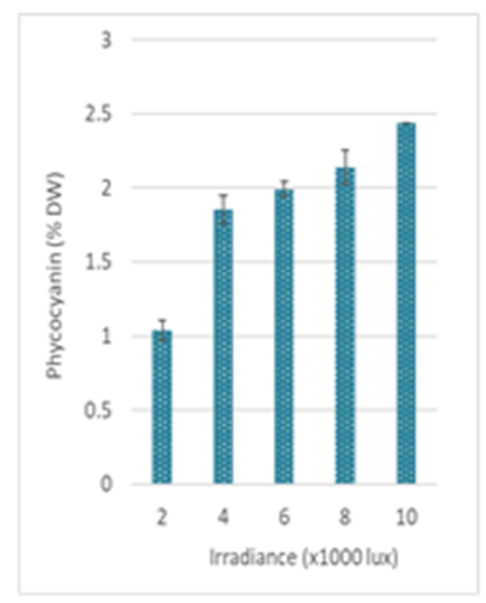

Figure 3. Comparison of total protein (a), chlorophyll-a (b), phycocyanin (c) under different irradiance. Data are expressed as mean values \pm deviation $(\mathrm{n}=3)$.

a)

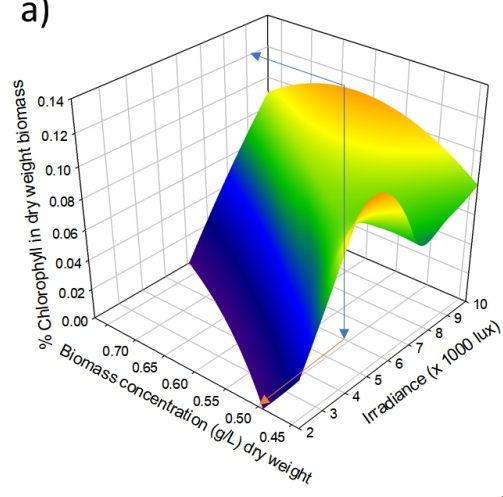

b)

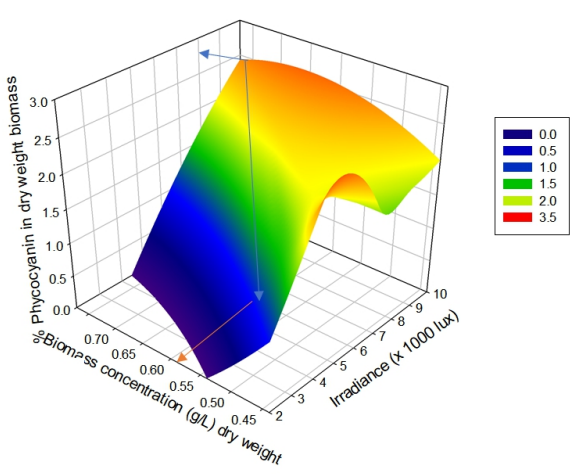

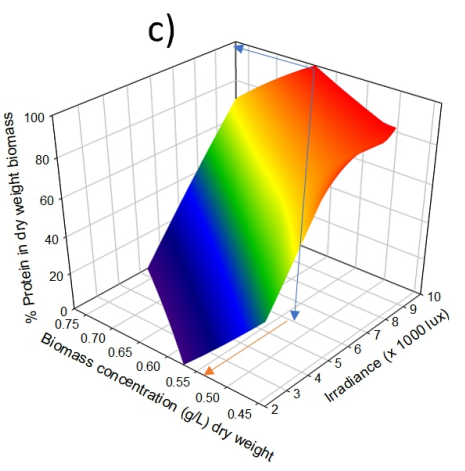

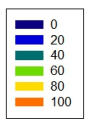

Figure 4. Three-dimensional fitting of different irradiance to the average values of biomass concentration towards chlorophyll-a content (a) against phycocyanin content (b), against protein content (c). 
Table 4. The result of dynamic fitting on non-linear regression for production of observed three metabolites. Visualization of these equations was as seen in Figures 4a to 4c.

\begin{tabular}{|c|c|c|}
\hline No & Equations & $\mathrm{R}^{2}$ \\
\hline 1 & $\begin{array}{l}\text { Protein production } \\
\text { Protein content } \\
=123.7+13.08 * \text { Irradiance } \\
-239.6 * \text { dry weight biomass }\end{array}$ & 0.979 \\
\hline 2 & $\begin{array}{l}\quad \text { Phycocyanin production } \\
\text { Phycocyanin content } \\
=7.27+0.99 * \text { Irradiance } \\
-31.63 * \text { dry weight biomass } \\
-0.09 * \text { Irradiance } 2+31.27 \\
* \text { dry weight biomass }{ }^{2}\end{array}$ & 1.000 \\
\hline 3 & $\begin{array}{l}\quad \text { Chlorophyll-a production } \\
\text { Chlorophyll - a content } \\
=0.29+0.05 * \text { Irradiance } \\
-1.41 * \text { dry weight biomass } \\
-0.005 * \text { Irradiance }{ }^{2}+1.44 \\
* \text { dry weight biomass }\end{array}$ & 1.000 \\
\hline
\end{tabular}

It was shown in Figures $4 \mathrm{a}$ and $4 \mathrm{~b}$ (formed as paraboloid curves) that irradiance of $10 \mathrm{k}$ lux significantly correlated to the maximum content both of chlorophyll-a and phycocyanin contents. This finding also fitted the second-order nonlinear equations of (2) and (3) in Table 4. It can be deducted from equation 2 and equation 3 that phycocyanin and chlorophyll-a contents are more strongly affected by the irradiance. This finding can be attributed to a photosynthetic mechanism that involves chlorophyll and phycobiliproteins (Ghorbani et al., 2014; Gonçalves et al., 2016; Gordillo et al., 1999; Gordillo et al., 2001).

In terms of protein production, there was a distinction from the other two previously mentioned metabolites. It was found that the optimum irradiance was observed in $6 \mathrm{k}$ lux (resulted from the highest protein content of $79.18 \%$ dry weight). Figure $4 \mathrm{c}$ also showed a different form (a plane curve) and followed a nonlinear-equation called a three-dimension-planar equation (equation 1 in Table 4).

The quality of model fitting was presented by the coefficient of the determination $\left(\mathrm{R}^{2}\right)$. Those models explained that more than $90 \%$ of dependent variables were adequately between experimental results and theoretical prediction. Therefore, the optimum condition of the production of the maximum metabolites has been successfully determined.

\section{CONCLUSION}

The production of chlorophyll-a, phycocyanin and protein from Spirulina fusiformis using the P.B.R. system in this study was maximized by optimizing irradiance through a Response Surface Methodology. The optimum irradiance for the protein content (maximum 79.18 $\pm 5.2 \%$ dry weight) was found under irradiance of $6 \mathrm{k}$ lux, while both for chlorophyll-a (maximum $0.090 \pm 0.023 \%$ dry weight) and phycocyanin (maximum $2.44 \pm 0.00 \%$ dry weight) were $10 \mathrm{k}$ lux.

Future studies will be carried out to optimize several other cultivation parameters (such as media composition, temperature, and mixing) but using fractional factorial design to reduce the number of experimental runs.

\section{ACKNOWLEDGEMENTS}

This study was supported by the grants of the PN-MALSAI-IPK-LIPI fiscal year of 2021. The authors also acknowledge the R.C. for Limnology and BBIL-LIPI, Lombok for financial support and facilities.

Authors' contribution: A.S. and T.C. have surveyed the literature, data processing, and 82 
writing the manuscript. I.A.S. has written few sections and review the final formatting of the manuscript.

\section{REFERENCES}

Akashi T, Okajima M, Kaneko T. 2008. Extraction of chromo proteins from Aphanothece sacrum and their applications to optically functional materials. Journal of Biotechnology, 136, Supplement, S450. https://doi.org/http://dx.doi.org/10.1016/j. jbiotec.2008.07.1045.

Andersen RA. 2005. Algal Culturing Techniques. Elsevier Inc.

APHA-AWWA. 1992. Water Environment Federation. Standard methods for the examination of water and wastewater (18 th ed.). Washington, DC.

Aslanbay Guler B, Deniz I, Demirel Z, Oncel SS, Imamoglu E. 2019. Comparison of different photobioreactor configurations and empirical computational fluid dynamics simulation for fucoxanthin production. Algal Research, 37, 195-204. https://doi.org/https://doi.org/10.1016/j.al gal.2018.11.019.

Bland E, Angenent LT. 2016. Pigment-targeted light wavelength and intensity promotes efficient photoautotrophic growth of Cyanobacteria. Bioresource Technology, 216 ,

579-586. https://doi.org/http://dx.doi.org/10.1016/j. biortech.2016.05.116.

Boussiba S, Richmond A. 1979. Isolation and purification of phycocyanins from the blue-green alga Spirulina platensis. Archive of Microbiology, 120, 155-159.

Chen CY, Kao PC, Tsai CJ, Lee DJ, Chang JS. 2013. Engineering strategies for simultaneous enhancement of Cphycocyanin production and $\mathrm{CO} 2$ fixation with Spirulina platensis. Bioresource Technology, 145, 307-312. https://doi.org/http://dx.doi.org/10.1016/j. biortech.2013.01.054.

Craggs R, Park J, Heubeck S, Sutherland D. 2014. High rate algal pond systems for lowenergy wastewater treatment, nutrient recovery and energy production. New
Zealand Journal of Botany, 52(1), 60-73. https://doi.org/10.1080/0028825X.2013.8 61855.

de Morais M, Vieira Costa J. 2007. Biofixation of carbon dioxide by Spirulina sp. and Scenedesmus obliquus cultivated in a three-stage serial tubular photobioreactor. Journal of Biotechnology, 129, 439-445. https://doi.org/10.1016/j.jbiotec.2007.01.0 09.

Dejsungkranont M, Chen HH, Sirisansaneeyakul S. 2017. Enhancement of antioxidant activity of C-phycocyanin of Spirulina powder treated with supercritical fluid carbon dioxide. Agriculture and Natural Resources, 51(5), 347-354. https://doi.org/https://doi.org/10.1016/j.an res.2017.12.001.

Draaisma RB, Wijffels RH, Slegers PM, Brentner LB, Roy A, Barbosa MJ. 2013. Food commodities from microalgae. Current Opinion in Biotechnology, 24(2), 169-177. https://doi.org/https://doi.org/10.1016/j.co pbio.2012.09.012.

Ghorbani A, Rahimpour HR, Ghasemi Y, Zoughi S, Rahimpour MR. 2014. A Review of Carbon Capture and Sequestration in Iran: Microalgal Biofixation Potential in Iran. Renewable and Sustainable Energy Reviews, 35, 73-100. https://doi.org/http://dx.doi.org/10.1016/j. rser.2014.03.013.

Gonçalves AL, Rodrigues CM, Pires JCM, Simões M. 2016. The effect of increasing $\mathrm{CO} 2$ concentrations on its capture, biomass production and wastewater bioremediation by microalgae and cyanobacteria. Algal Research, 14, 127136.

https://doi.org/http://dx.doi.org/10.1016/j. algal.2016.01.008.

González López CV, García MdCC, Fernández FGA, Bustos CS, Chisti Y, Sevilla JMF. 2010. Protein measurements of microalgal and cyanobacterial biomass. Bioresource Technology, 101(19), 7587-7591. https://doi.org/https://doi.org/10.1016/j.bi ortech.2010.04.077.

Gordillo F, Jimenez C, Figueroa F, Niell F. 1999. Effects of increased atmospheric $\mathrm{CO} 2$ and 
$\mathrm{N}$ supply on photosynthesis, growth and cell composition of the cyanobacterium Spirulina platensis (Arthrospira). Journal of Applied Phycology, 10, 461-469.

Gordillo FJL, Jiménez C, Goutx M, Niell X. 2001. Effects of $\mathrm{CO} 2$ and nitrogen supply on the biochemical composition of Ulva rigida with especial emphasis on lipid class analysis. Journal of Plant Physiology, $158(3)$, 367-373. https://doi.org/http://dx.doi.org/10.1078/0 176-1617-00209.

Ho SH, Lu WB, Chang JS. 2012. Photobioreactor strategies for improving the $\mathrm{CO}_{2}$ fixation efficiency of indigenous Scenedesmus obliquus CNW-N: Statistical optimization of $\mathrm{CO}_{2}$ feeding, illumination, and operation mode. Bioresource Technology, 105 ,

106-113. https://doi.org/http://dx.doi.org/10.1016/j. biortech.2011.11.091.

Jacob-Lopes E, Cacia Ferreira Lacerda LM, Franco TT. 2008. Biomass production and carbon dioxide fixation by Aphanothece microscopica Nägeli in a bubble column photobioreactor. Biochemical Engineering Journal, 40(1), 27-34. https://doi.org/http://dx.doi.org/10.1016/j. bej.2007.11.013.

Jacob-Lopes E, Scoparo CHG, Franco TT. 2008. Rates of $\mathrm{CO}_{2}$ removal by Aphanothece microscopica Nägeli in tubular photobioreactors. Chemical Engineering and Processing: Process Intensification, 47(8), 1365-1373. https://doi.org/http://dx.doi.org/10.1016/j. cep.2007.06.004.

Johnson T, Katuwal S, Anderson G, Gu L, Zhou R, Gibbons W. 2018. Photobioreactor Cultivation Strategies for Microalgae and Cyanobacteria. Biotechnology Progress, 34. https://doi.org/10.1002/btpr.2628.

Koller M, Muhr A, Braunegg G. 2014. Microalgae as versatile cellular factories for valued products. Algal Research, 6, 52-63.

https://doi.org/https://doi.org/10.1016/j.al gal.2014.09.002.

Lowry OH, Rosebrough JN, Farr A, Randall R. 1951. Protein measurement with the
Folin Phenol Reagent. The Journal of Biological Chemistry, 193, 265-275.

Mary Leema JT, Kirubagaran R, Vinithkumar NV, Dheenan PS, Karthikayulu S. 2010. High value pigment production from Arthrospira (Spirulina) platensis cultured in seawater. Bioresource Technology, 101(23), 9221-9227. https://doi.org/http://dx.doi.org/10.1016/j. biortech.2010.06.120.

Michael A, Kyewalyanga MS, Lugomela CV. 2019. Biomass and nutritive value of Spirulina (Arthrospira fusiformis) cultivated in a cost-effective medium. Annals of Microbiology, 69(13), 13871395. https://doi.org/10.1007/s13213-01901520-4.

Mohsenpour SF, Willoughby N. 2016. Effect of $\mathrm{CO}_{2}$ aeration on cultivation of microalgae in luminescent photobioreactors. Biomass and Bioenergy, 85, 168-177. https://doi.org/http://dx.doi.org/10.1016/j. biombioe.2015.12.002.

Morais MGd, Costa ALH. 2007. Biofixation of carbon dioxide by Spirulina $s p$. and Scenedesmus obliquus cultivated in a three-stage serial tubular photobioreactor. Journal of Biotechnology, 129, 439-445. https://doi.org/10.1016/j.jbiotec.2007.01.0 09.

Ores JdC, Amarante MCAd, Kalil SJ. 2016. Coproduction of carbonic anhydrase and phycobiliproteins by Spirulina sp. and Synechococcus nidulans. Bioresource Technology, 219, 219-227. https://doi.org/http://dx.doi.org/10.1016/j. biortech.2016.07.133.

Rangel-Yagui Cde O, Danesi ED, de Carvalho JC, Sato S. 2004. Chlorophyll production from Spirulina platensis: cultivation with urea addition by fed-batch process. Bioresource Technology, 92(2), 133-141. https://doi.org/10.1016/j.biortech.2003.09. 002 .

Vanthoor-Koopmans M, Wijffels RH, Barbosa MJ, Eppink MHM. 2013. Biorefinery of microalgae for food and fuel. Bioresource Technology, 135, 142-149. https://doi.org/https://doi.org/10.1016/j.bi ortech.2012.10.135. 
Whitton R, Ometto F, Pidou M, Jarvis P, Villa R, Jefferson B. 2015. Microalgae for municipal wastewater nutrient remediation: mechanisms, reactors and outlook for tertiary treatment. Environmental Technology Reviews, 4(1), 133-148. https://doi.org/10.1080/21622515.2015.11 05308 .

Zhao B, Su Y, Zhang Y, Cui G. 2015. Carbon dioxide fixation and biomass production from combustion flue gas using energy microalgae. Energy, 89, 347-357. https://doi.org/http://dx.doi.org/10.1016/j. energy.2015.05.123. 